\title{
Potencjały i relacje uniwersytetu w społeczeństwie i gospodarce opartej na wiedzy
}

\section{Wprowadzenie}

Obecnie zasoby bibliograficzne w obszarze funkcjonowania sieci relacji między uniwersytetem, władzą, gospodarką i społeczeństwem są niezwykle skromne, podobnie jak ramy artykułu. Ograniczyły one możliwość szerszego wyjaśnienia procesu, przenikania się zarówno tradycyjnych, jak i obecnych interesów instytucjonalno-organizacyjnych, relacji, kodów kulturowych, informacyjnych, komunikacyjnych, innowacji oraz kontroli w sieci współdziałania. W tak niezwykle złożonym i wielowymiarowym kontekście problemowym, wiele trudności sprawia nie tylko identyfikacja czynników, zmiennych i wskaźników, ale także każda próba ich sparametryzowania i diagnozowania.

Jednak z dużą dozą pewności można powiedzieć, że szersze przedstawienie tego procesu nawet w najbliższej przyszłości będzie wymagało wysiłku poznawczego oraz solidnego przygotowania merytorycznego i metodycznego, głównie członków interdyscyplinarnych zespołów badawczych, którzy zdecydują się podjąć implementacji dotychczasowych osiągnięć badawczych do praktyki. Jednak, aby były one uznane w środowisku teoretyków i praktyków za naukowe wymagają szerokiego ich upowszechnienia, prowadzenia negocjacji i dyskusji, obserwacji, analiz, parametryzacji wskaźników oraz analizy rachunku kosztów. Obecnie niezwykle ważne jest zidentyfikowanie nowych obszarów 
badawczych, co pozwoliłoby na prawidłowe ukierunkowanie strategii badawczych, w tym identyfikację głównych i peryferyjnych elementów architektury sieci relacji, interesów, przepływów informacyjnych i komunikacyjnych. A także określenie ich parametrów, wskaźników i zmiennych w celu adaptowania ich do naszego racjonalnego sposobu myślenia i zrozumienia oraz empirycznego badania zasad ich działania. Efektem podjętych działań koncepcyjno-planistyczno-wdrożeniowych i ewaluacyjnych powinno być m.in. opracowanie nowego modelu funkcjonowania uniwersytetu opartego na sieci wielokierunkowych i wielopoziomowych relacji zachodzących między zespołami pracowników dydaktycznych i naukowo-badawczych, wielością źródeł finansowania badań, staży, stypendiów, praktyk, laboratoriów i warsztatów a optymalizacją ponoszonych kosztów ich funkcjonowania.

Podjęte działania umożliwiłyby wzbogacenie przestrzeni społecznej uniwersytetów o bardziej transparentną perspektywę relacyjną i zadaniową ${ }^{1}$ oraz lepsze pozycjonowanie naszych uniwersytetów w strukturze społeczno-gospodarczej. Powinno temu służyć kreowanie i projektowanie nowych relacji ze społecznościami, władzą publiczną, organizacjami pozarządowymi i gospodarką rynkową, w których główną rolę pełnią wielokierunkowe przepływy danych, informacji, wiedzy, modeli, koncepcji oraz zmiany postaw i zachowań2 ${ }^{2}$

Ważnym etapem powyższych ewolucyjnych i aksjologicznych zmian w sieciach o charakterze funkcjonalno-strukturalnym i koordynacji będzie osiągnięcie pełnej ich dojrzałości. Kolejne etapy zmian będą związane z wzrastającą złożonością sieci relacji i koordynacji działań. Proces ten będzie wymagał w skali makro:

- odejścia od gospodarki etatystycznej poprzez odbiurokratyzowanie instytucji i organizacji, w tym uniwersytetów;

- zaadaptowania nowoczesnych sieciowych systemów informacyjno-informatycznych, przygotowania kompetentnych menedżerów do spraw administrowania i zarządzania sieciami relacji, w tym do podejmowania decyzji oraz zlecania zadań i monitorowania działań;

$1 \quad$ N. Elias, Społeczeństwo jednostek, Wydawnictwo Naukowe PWN Warszawa 2008, s. 26.

2 M. Castells, Społeczeństwo sieci, Wydawnictwo Naukowe PWN, Warszawa 2008, s. 34; Idem, Koniec tysiąclecia, Wydawnictwo Naukowe PWN Warszawa 2009, s. 308. 
- poszukiwanie obszarów do wprowadzania innowacyjnych rozwiązań i efektywne zarządzanie kapitałem ludzkim;

- opracowywania wielowymiarowych i wielopoziomowych strategii rozwoju opartych na wynikach badań empirycznych i stosowanie ich w praktyce,

- wprowadzanie innowacji poprzez zmiany w strukturach organizacyjnych, programach działania i współdziałania ze sobą różnych pod względem liczby i złożoności relacji sieciowych między wieloma podmiotami.

Przechodzenie do każdego wyższego etapu będzie jednak w dużej mierze zależało od osiągniętego poziomu zaawansowania modelu zrównoważonego rozwoju gospodarki rynkowej opartej na nowoczesnych bazach danych i bazach wiedzy w Polsce. W skali globalnej gospodarki dokonuje się proces profesjonalizacji kadr i pracowników w korporacjach i przedsiębiorstwach o orientacji komunikacyjnej i informacyjnej opartych na informacjonizmie ${ }^{3}$. Natomiast w sferze społecznej dokonuje się powolne przechodzenie od myślenia plemiennego i wspólnotowego do regionalnego, grupowego i indywidualnego.

Informacjonizm charakteryzuje się szerokim wykorzystaniem Internetu, nowymi źródłami do jego dostępu i zasilania. Przebiega on zgodnie z rozwojem techniki i technologii oraz logiką rozwoju zaawansowanych centrów usług globalnych i przepływów finansowych. Wskazuje to wyraźnie na potrzebę łączenia strategii biznesowych z poszukiwaniem nowej wiedzy naukowej poprzez różnego rodzaju badania, aby było możliwe doskonalenie teorii i praktyki. Ich rozwój wymaga podejmowania coraz bardziej działań pragmatycznych, standardowych, elastycznych relacji między faktami społecznymi a ich wartościowaniem, krytycznej i obiektywnej oceny zmian w dotychczas dominującym kodzie kulturowym, preferowaniu efektywności wewnętrznej i zewnętrznej oraz ścisłej koordynacji sieciowej systemów współzarządzania ${ }^{4}$ opartych na zarządzaniu procesowym ${ }^{5}$.

$3 \quad$ N. Klein, Doktryna szoku. Jak współczesny kapitalizm wykorzystuje klęski żywiołowe i kryzysy społeczne, Wydawnictwo Muza SA, Warszawa 2014, s. 218.

4 C. Levi-Stauss, The Elementary Structures of Kinship, Boston Press, Boston 1969. Zdaniem autora ludzie wyposażeni są w instytucjonalne dziedzictwo złożone z norm i wartości.

5 A. Bitkowska, Zarządzanie procesowe we współczesnych organizacjach, Wydawnictwo Difin, Warszawa 2013, s. 119. 
Istotnym etapem na polskiej drodze projektowania nowego modelu relacji uczelni z innymi instytucjami i organizacjami powinno być nawiązywanie do założeń twórców Szkoły Lwowsko-Warszawskiej, w tym Kazimierza Twardowskiego ${ }^{6}$ i Tadeusza Kotarbińskiego. Odzwierciedla ona bowiem polskie korzenie filozofii bazującej na podmiotowości człowieka i podejmowanych przez niego efektywnych działaniach. Przejawia się to w preferowaniu logicznego myślenia i komunikowania oraz tolerancji dla różnych poglądów, skromności, systematyczności ${ }^{7}$ oraz potrzebie budowania polskiej filozofii myślenia i prakseologicznego działania ${ }^{8}$.

Warto jednak podkreślić, że już zauważalnymi formami kapitalizacji posiadanych zasobów edukacyjnych są wprowadzane w uniwersytetach i gospodarce innowacje organizacyjne, w formie: start-upów, biur transferu technologii, inkubatorów biznesu, parków technologicznych, laboratoriów i centrów badawczych.

Warto jednak podkreślić, że z jednej strony wzrasta presja wywierana na naukowców, aby osiągali sukcesy przy ograniczonych kosztach badań ze strony państwa, ale z drugiej coraz bardziej poszerza się współpraca z biznesem zarówno za honoraria i pensje, jak i dla poszukiwania prawdy, sławy i uznania9 ${ }^{9}$ Badacze akademiccy upodabniają się w ten sposób nie tylko do personelu firm prywatnych, ale dochodzi również do upodabniania się struktur organizacyjnych i zarządzania personelem w uniwersytetach z przedsiębiorstwami - aczkolwiek jest to dopiero etap wstępny. Zauważalne jest już wdrażanie w nich podobnych rozwiązań w organizacji i zarządzaniu jakością, zarządzaniu personelem i projektami, co powinno zaowocować zacieśnianiem współpracy badaczy akademickich ze specjalistami od polityki, administracji publicznej i gospodarki. Sprzyjać temu powinien proces realizacji projektów wdrożeniowych potrzebnych społeczeństwu,

6 K. Twardowski, O dostojeństwie Uniwersytetu, „Zagadnienia Naukoznawstwa” 1990, nr 3, s. 74 .

7 J. Woleński, Filozoficzna szkoła lwowsko-warszawska, PWN, Warszawa 1985, s. 13.

8 L. Stachurski, Kazimierz Twardowski wobec filozofii polskiej, [w:] W. Słomski (red.) Twórca szkoły lwowsko-warszawskiej w 70. Rocznice śmierci Kazimierza Twardowskiego, Wydawnictwo Wyższej Szkoły Finansów i Zarządzania, Warszawa 2008, s. 33.

$9 \quad$ P. Sztompka, Zaufanie. Fundament społeczeństwa, Wydawnictwo Znak, Kraków 2007, s. 374. 
gospodarce i ekologii. Projekty te są już współfinansowane zarówno przez przedsiębiorstwa, państwo, Unię Europejską, uczelnie i fundacje. A ponadto, wspierane przez międzynarodowe, międzyuczelniane i uczelniane interdyscyplinarne zespoły naukowo-badawcze.

Obecnie potrzebne są wielowymiarowe, długookresowe, dwustronne (uniwersytet-gospodarka) i trójstronne (uniwersytet-gospodarka-społeczeństwo) przepływy informacji, wiedzy i doświadczeń oraz rozwiązań innowacyjnych w ramach modelu badania, rozwoju, innowacji i implementacji $(B+R+I+I)$. Świadczą o tym przykłady tworzenia firm oraz realizowanych projektów badawczych w takich dziedzinach jak: biotechnologia, nanotechnologia, chemia budowlana, mechatronika, farmacja, grafika komputerowa czy energia odnawialna. Lepsze zrozumienie tych niezwykle złożonych problemów, które najczęściej posiadają strukturę sieci oraz różne poziomy gromadzenia, przechowywania, selekcji i wykorzystania wiedzy.

\section{Zarys relacji uniwersytet - gospodarka - władza - społeczeństwo}

Zacieśnianie powyższych realizacji wymaga nie tylko efektywnego zastosowania modelu B. Clarka i wynikających z niego modeli pośrednich, ale przede wszystkim wielowymiarowego modelu potrójnej i poczwórnej spirali, których założenia opracowali Henry Etzkowitz i Loet Leydesdorff ${ }^{10}$. Ich zdaniem, zanim jednak rozpocznie się etap planistyczny i organizacyjno-wdrożeniowy to powinno się wcześniej dokonać solidnej diagnozy m.in. aby uzyskać odpowiedź na następujące pytania:

Jaka jest struktura i dynamika zaangażowania uniwersytetów, społeczeństwa, władzy i przemysłu w ten proces? W jaki sposób poziom ich rozwoju wpływa na rozwiązywanie problemów w obszarze badań, rozwoju i wdrażania innowacji? Obecnie już dość dużo wiemy o sieciowych strategiach rozwoju organów administracji państwowej, rządowej i samorządowej, które powinny być jeszcze bardziej zogniskowane na absorpcji informacji, wiedzy, modeli, algorytmów i procedur od

10 H. Etzkowitz, L. Leydesdorff, Universities and the Global Knowledge Economy. A Triple Helix of University-Industrial-Government Relations, (red.) J. de la Mothe, G. Paquet, London 1997. 
uniwersytetów do przemysłu i sfery usług ${ }^{11}$. Organy te sprawują niezwykle ważną rolę w zarządzaniu zasobami, jakimi dysponują państwo i społeczeństwo. Powinny one jeszcze bardziej bezpośrednio angażować w pomoc we wdrażaniu potrzebnych nowych technologii i subsydiowaniu strategicznych kontraktów między przedsiębiorstwami a uniwersytetami, aby ograniczać luki w wiedzy oraz bariery w procesie tworzenia warunków dla rozwoju techniki i technologii, które mają istotne znaczenie dla przyszłego rozwoju produkcji i usług potrzebnych dla społeczeństwa.

Rola organów administracji rządowej (wykonawczej) w odniesieniu do uniwersytetów i przedsiębiorstw ewoluuje zarówno w zakresie wspierania instytucji akademickich $\mathrm{w}$ przekraczaniu tradycyjnych funkcji kulturowej, dydaktycznej i naukowo-badawczej, jak i funkcji kontrolnej w realizacji strategii państwa odpowiedzialnego rozwoju. Rysunek 1. przedstawia miejsce uniwersytetu w relacjach do gospodarki rynkowej, społeczeństwa, rządu i samorządu.

\section{Rysunek 1. Uniwersytet społecznie odpowiedzialny}

\begin{tabular}{|c|c|c|c|c|c|c|}
\hline & & \multicolumn{3}{|c|}{ OCZEKIWANIA } & & \\
\hline \multirow{5}{*}{$\begin{array}{l}\mathrm{S} \\
\mathrm{t} \\
\mathrm{u} \\
\mathrm{d} \\
\mathrm{e} \\
\mathrm{n} \\
\mathrm{c} \\
\mathrm{i}\end{array}$} & & \multicolumn{3}{|c|}{ REGULATORY } & \multirow{4}{*}{$\begin{array}{l}\mathrm{P} \\
\mathrm{r} \\
\mathrm{a} \\
\mathrm{w} \\
\mathrm{o}\end{array}$} & \multirow{5}{*}{$\begin{array}{l}\mathrm{B} \\
\mathrm{i} \\
\mathrm{z} \\
\mathrm{n} \\
\mathrm{e} \\
\mathrm{s}\end{array}$} \\
\hline & \multirow{3}{*}{$\begin{array}{l}\mathrm{R} \\
\mathrm{y} \\
\mathrm{n} \\
\mathrm{e} \\
\mathrm{k}\end{array}$} & \multicolumn{3}{|c|}{ ZDOLNOŚCI ADAPTACYJNE } & & \\
\hline & & & $\begin{array}{l}\text { Władze uczelni } \\
\text { Pracownicy }\end{array}$ & & & \\
\hline & & \multicolumn{3}{|c|}{ Zarządzanie wiedzą } & & \\
\hline & & \multicolumn{3}{|c|}{ Presja społeczna } & & \\
\hline & \multicolumn{2}{|c|}{ Społeczeństwo } & Rząd i samorząd & \multicolumn{2}{|c|}{ Sektor społeczny } & \\
\hline
\end{tabular}

Źródło: e-mentor. edu.pl (dostęp: 07.09.2019).

11 P. Modzelewski, K. Opolski (red.), Metodologia pomiaru sieci administracji publicznej, Wydawnictwo CeDeWu, Warszawa 2014, s. 13. 
Analiza historyczno-porównawcza wskazuje, że rządy państw demokratycznych stosują coraz to bardziej złożone strategie działania. Jedne pełnią aktywną rolę we wdrażaniu własnych innowacji w gospodarce, inne korzystają z pomocy korporacji międzynarodowych, a jeszcze inne powoli wycofują się z całkowitej kontroli i finansowania polityki naukowo-badawczej, na rzecz budowania ich autonomii lub też realizują reformy pozorne obliczone głównie na efekt populistycznie rozumianego marketingu politycznego ${ }^{12}$.

Instytucje międzynarodowe, takie jak Unia Europejska, Bank Światowy i ONZ wspierają rozwój, ale przede wszystkim państw wysoko rozwiniętych, których gospodarka opiera się na płynnym transferze wiedzy poprzez coraz bardziej złożone konfiguracje sieciowe ${ }^{13}$.

\section{Znaczenie relacji sieciowych w przepływie wiedzy i informacji}

W Polsce, podobnie jak i w innych państwach Europy Środkowej, istnieje poważna luka innowacyjna $\mathrm{w}$ obszarze nowoczesnych technik i technologii, pomimo prób skracania skali czasowej pomiędzy badaniami, wdrażaniem a efektami końcowymi oraz pomiędzy zasobami komunikacyjnymi i finansowymi dostępnymi dla uniwersytetów i przedsiębiorstw a potrzebami ich wdrażania. Obecnie już nie tylko ekonomiści w Polsce są głęboko przekonani, że istnieje pilna potrzeba wdrożenia nowego programu przejścia od deindustrializacji ${ }^{14}$ do nowoczesnej reidustrializacji technologicznej na poziomie $4.0^{15}$.Zwracają oni uwagę, że w dużej mierze musimy ten etap modernizacji zrealizować sami, zdając sobie sprawę z osiągnięć, jak i patologii polskiej prywatyzacji i modernizacji okresu początkowej transformacji ${ }^{16}$. Dlatego

12 H. Etzkowitz, Losing our bearings: the science policy crisis in post-Cold War Eastern Europe, former Soviet Union and USA, „Science and Public Policy” 1996, t. 23(1), s. 13-26.

13 J. Stiglitz J., Globalizacja, Wydawnictwo Naukowe PWN, Warszawa 2004.

14 A. Karpiński, S. Paradysz, P. Soroka, W. Żółtkowski, Od uprzemysłowienia w PRL do dezindustrializacji kraju, Wydawnictwo Muza SA, Warszawa 2015.

15 Konwersatorium Polskiego Towarzystwa Ekonomicznego nt. Patologiczne aspekty polskiej prywatyzacji, z 13 października 2016 roku.

16 W. Kieżuń, Drogi i bezdroża polskich przemian, Wydawnictwo EKTV Sp. z o.o., Warszawa 2011, s. 192. 
też istnieje potrzeba zacieśniania współpracy naukowej, gospodarczej i politycznej w skali narodowej, międzynarodowej i globalnej.

Aby włączyć się w ten proces i spełnić powyższe standardy władze publiczne, uniwersytety i biznes muszą wypracować wspólną długookresową strategię działania ukierunkowaną na rozwój kompetencji społecznych, kognitywnych, technicznych i koncepcyjnych absolwentów szkół średnich i wyższych oraz podniesienie nakładów na budowę laboratoriów i parków technologicznych wyposażonych w najnowocześniejszą technikę i technologię, jakie są niezbędne do wdrażania innowacji. W ten sposób będzie możliwe monitorowanie procesu ograniczania luki między poziomem rozwoju personelu korporacji międzynarodowych i dużych przedsiębiorstw a kwalifikacjami i kompetencjami zawodowymi absolwentów uniwersytetów.

Luki głównie w wiedzy i umiejętnościach nie tylko z niedoskonałości funkcjonowania elementów podmiotowych systemu kształcenia w Polsce, ale głównie ze względu na małą liczbę dobrze wyposażonych centrów technicznych, warsztatów i laboratoriów potrzebnych do badań nad rozwojem produktów, usług i handlu. Powinny one posiadać potencjał do tworzenia innowacyjnych produktów i procesów oraz ich ciągłego doskonalenia. Jest to możliwe dzięki ścisłej współpracy uniwersytetów z przemysłem, biznesem i władzą, które powinny łączyć wspólne siły, by skuteczniej służyć przede wszystkim praktycznym potrzebom gospodarki korzystając z jej zasobów poprzez preferowanie myślenia twórczego i innowacyjnego.

Nie należy jednak zapominać o profesjonalizacji i specjalizacji, w tym głównie w zakresie nauk ścisłych matematyki, fizyki, chemii i biologii, których brakuje absolwentom szkół podstawowych, średnich i wyższych. A które w dużej mierze decydują o osiągnięciu wyższej pozycji zawodowej i wynagrodzeniu. Obserwuje się, że doświadczeni nauczyciele matematyki są zastępowani wprawdzie przez lepiej wykształconych, ale nie na wydziałach matematycznych i nauk ścisłych absolwentów. Bardzo często nie posiadają oni doświadczenia i kompetencji pedagogicznych. Od wielu lat w Polsce ten problem nie jest rozwiązywany, a wyniki egzaminów już na poziomie szkół podstawowych i egzaminów w szkołach podstawowych, gimnazjalnych i średnich zmuszają nie tylko do bardzo głębokich refleksji, głównie rodziców, aby ich dzieci korzystały z korepetycji. Należy więc odejść od mało transparentnej rekrutacji i przygotowania nauczycieli matematyki, 
fizyki i chemii w szczególności oraz od jednolitego systemu i niskiego poziomu ich wynagradzania. To jest $\mathrm{z}$ gruntu zła praktyka, która nie premiuje profesjonalizmu i nabywania potrzebnych obecnie i w przyszłości wiedzy, umiejętności i kompetencji.

Istnieje więc obiektywna konieczność łączenia zewnętrznych i wewnętrznych źródeł innowacji poprzez możliwości korzystania przez studentów z laboratoriów uczelnianych i przemysłowych w zakresie ich liczby oraz skali i zakresu działania. Laboratoria, pracownie i centra techniczne to jednostki badawcze, które stanowią kluczowy element w nowoczesnych systemach technicznych i technologicznych postrzeganych jako sieć agentów zmiany - sprawstwa ${ }^{17}$. Powyższe zmiany w gospodarce wpływają na zmiany w innych elementach infrastruktury wiedzy i umiejętności. Dotychczasowa praktyka oparta na sztywnych granicach instytucjonalno-organizacyjnych i transakcyjnych warunkach rynkowych, powinna być zastąpiona konsultacjami, negocjacjami warunków między uczelniami, firmami i organizacjami pożytku publicznego i ukierunkowana na zaspokajanie potrzeb społecznych ${ }^{18}$.

W powoli zmieniającej się rzeczywistości społeczno-gospodarczej uniwersytety coraz częściej postrzegane są jako ważni aktorzy w krajowych i międzynarodowych systemach innowacji, a poszczególne granice są usuwane i zastępowane przez sieci powiązań. Dlatego też, powstające instytuty o profilu naukowo-badawczym powinny efektywnie decentralizować swoje działania związane z własnością intelektualną i transferem technologii, zarówno pomiędzy sobą, jak i podmiotami gospodarczymi jako kontrahentami i klientami. Warto jednak pamiętać, że wprowadzaniu nowych zasad i rozwiązań, towarzyszą tradycyjne postawy i zachowania oraz normy i wartości, które tworzą złożoną sieć powiązań pomiędzy organizacjami. Niestety często są one sprawcami generowania konfliktów instytucjonalno-organizacyjnych i interpersonalnych o zróżnicowanej intensywności i przebiegu.

W miarę jak uniwersytety będą zdobywały uznanie i szacunek społeczeństwa poprzez budowanie swojej silnej marki, głównie wśród przedsiębiorców i samorządów, to będzie następował również transfer

\footnotetext{
17 Ibidem, s. 82.

18 T.E. Gieryn, Boundary-work and the demarcation of science form non-science: strains and interests in professional ideologies of scientists, „American Sociological Review” 1983, nr 48, s. 95.
} 
posiadanej przez nie wiedzy, który będzie wymuszał potrzebę jej ustawicznego generowania.

Budowany w ten sposób nowy model infrastruktury instytucjonalnej, powinien mieć również zdolność do łączenia pozyskanych środków finansowych z rozmaitych źródeł oraz tworzenia różnych kanałów upowszechniania wiedzy, technicznej i technologicznej oraz społecznej dla różnorodnych instytucji i organizacji. W takiej sytuacji grupy badawcze w firmach będą stawały się elementem wspólnych przedsięwzięć badawczych i długoterminowych sojuszy, czy też aliansów strategicznych. Będą umożliwiały lepsze komunikowanie się personelu laboratoriów instytucji państwowych, pracowni badawczych i biznesowych z zespołami badawczymi uniwersytetów w celu wspólnego rozwiązywania, ważnych zarówno dla zainteresowanych stron, jak i społeczeństwa i środowiska naturalnego problemów.

Wzajemne dopasowywanie strategii naukowo-badawczych uniwersytetów, władzy publicznej i podmiotów gospodarczych pod względem naukowym, prawnym, finansowym, technicznym i technologicznym stanowi więc niezwykle ważne wyzwanie szczególnie dla projektantów i zarządzających strukturami sieciowymi funkcjonującymi w tych podmiotach. Jednak integracja strategii organizacyjnych wymaga posiadania wysokich kompetencji merytorycznych i metodologicznych w zakresie planowania, organizacji i kontroli funkcjonowania sieci zarządzania wieloma podmiotami jednocześnie ${ }^{19}$, pomiaru ilościowego i jakościowego, oceny ryzyk i zagrożeń ${ }^{20}$ oraz negocjacji w zakresie obszarów zastosowań nauki, techniki i technologii przez państwo, przemysł i środowisko akademickie. Przekonania i poglądy oraz formułowane oceny i opinie dotyczące poziomu i rodzaju interwencji w poszczególnych obszarach stają się obecnie elementami krytycznymi o wysokim poziomie ryzyk i zagrożen. Są to obecnie centralne problemy, dotyczące realiów akademickich, gospodarki i władzy, które wykorzystują różne teorie i praktyki gospodarczej a w zależności od poziomu ich rozwoju.

19 P. Modzelewski, K. Opolski (red.), Metodologia pomiaru funkcjonowania sieci administracji publicznej, Wydawnictwo CeDeWu, Warszawa 2014, s. 51.

20 A. Damodaran, Ryzyko strategiczne, Wydawnictwa Akademickie i Profesjonalne, Warszawa 2009, s. 96-97. 


\section{Ramy teoretyczne potrójnej spirali modelu Henry'ego Etzkowitza i Loeta Leydesdorffa}

Potrójna spirala, która obejmuje złożone relacje zachodzące między uniwersytetami, przemysłem i władzą jest, zdaniem H. Etzkowitza i L.A. Leydesdorffa, kluczowym elementem każdej krajowej strategii innowacji początku XXI wieku. Relacje i interakcje, jakie zachodzą między uczelniami, przemysłem i władzą publiczną przejawiają się w polityce badań naukowych. Dotychczas dominowały głównie liniowe modele struktur organizacyjnych kreowania popytu i podaży, które obecnie są zastępowane przez modele ewolucyjne oparte na koncepcji zrównoważonego rozwoju w ujęciu systemowym $\mathrm{w}$ formie sieci zależności i współrządzenia ${ }^{21}$. Warto jednak pamiętać, że nieliniowa dynamika rozwoju wymusza stosowanie modeli co-ewolucyjnych, które lepiej opisują i wyjaśniają sposoby, w jaki ewoluują technologie, a w ślad za nimi organizacje i instytucje $\mathrm{e}^{22}$. Dlatego też niezwykle ważne jest opracowanie diagnozy głównych determinant ich pojawiania się i znikania. Kiedy można zatem uznać, że są one już częścią nowej infrastruktury instytucjonalno-organizacyjnej. Jak można unikać lub ograniczać oddziaływania czynników niekorzystnych? A ponadto, jak zmiany zachodzące w strukturze społecznej oddziałują na zmiany lub cykle zmian w infrastrukturze ekonomiczno-technologicznej?

Zdaniem H. Etzkowitza i L. Leydesdorffa badania wskazują przede wszystkim na trzy źródła mające wpływ na zachodzenie powyższych zmienności. Pierwszym, jest sektor przemysłowy, który różni się przebiegiem ewolucji techniki technologii, jaka jest niezbędna dla rozwoju tego sektora. Drugim są techniki i technologie, które generują różne wzorce innowacji i ich dyfuzji. Trzecim są systemy innowacji, które integrują i różnicują wykonywanie różnych funkcji, czasami w odmienny sposób. Mają one zarówno charakter strukturalno-funkcjonalny, jak i organizacyjno-instytucjonalny. Z jednej strony, sektory instytucjonalne (publiczne i prywatne), które wcześniej funkcjonowały

21 R. Nelson, S. Winter, An Evolutionary Theory of Economic Change. Belknap Press of Harvard University Press, Cambridge 1982.

22 R. Nelson, Economic Growth via the coevolution of Technology and Institution, [w:] L.A. Leydesdorff, P. van de Besselaar, P. Murray Allen (red.), Evolutionary Economic and Chaos Theory: New Directions in Technology Transfer, Pinter, London 1994, s. 21. 
na zasadach rynkowych, coraz częściej współpracują ze sobą na zasadzie spiralnych układów powiązań, które pojawiają się na różnych etapach $\mathrm{w}$ trakcie tworzenia nowego środowiska innowacyjnego. A z drugiej strony, firmy typu start-up powstają często w wyniku integracji wspomnianych powyżej trzech sektorów lub czterech sektorów akademickich grup badawczych, krajowych parków technologicznych oraz laboratoriów dużych firm i korporacji, a także otoczenia społecznego i ekologicznego.

Proces rozwoju innowacji, który odbywa się na poziomie krajowym, dokonuje się poprzez współpracę między organami samorządu terytorialnego oraz konkurującymi ze sobą przedsiębiorstwami. System innowacji państwa obecnie jest uzupełniany regionalnymi systemami innowacji zarówno w krajach Unii Europejskiej, jak i poza nią. Na poziomie wojewódzkim nie jest to nowość, natomiast na poziomie poznawczym dla naukowców, którzy reprezentują różne dziedziny i dyscypliny nauk oraz specjalistów stanowi to niezwykle trudne wyzwanie, gdyż wymaga pokonania pewnych materialnych i niematerialnych granic w poszukiwaniu nowych form kooperacji i integracji.

W polityce technologicznej naturalne jest, że uczelnie, województwa i powiaty oraz rozwój sfery usług, handlu i przedsiębiorstw w Polsce są mocno zróżnicowane pod względem zorientowania na badania, rozwój i innowacje. Powinny zatem silne województwa i powiaty wymieniać doświadczenia $\mathrm{w}$ zależności od osiągniętego poziomu rozwoju społeczno-ekonomicznego. Można więc oczekiwać, że uzyskanie przewagi konkurencyjnej wymaga wprowadzenia na krótki lub dłuższy czas celowej regulacji dla różnych poziomów integracji i kontroli. Obecnie wiele międzynarodowych programów Unii Europejskiej i Międzynarodowego Banku Światowego wspiera makroekonomiczny i regionalny rozwój gospodarczy, opierając się na raportach i zaleceniach formułowanych przez ekspertów ze środowiska akademickiego, przemysłowego i rządowego, aby osiągnąć swoje cele. Nowoczesne sposoby produkcji pojawiają się w oparciu o powiązania między środowiskiem akademickim, przemysłem i rządem.

Rozwój ten znajduje odzwierciedlenie w rosnącej konwergencji między USA, Japonią i krajami Unii Europejskiej w zakresie nauki, polityki technologicznej oraz rozwoju przemysłu. Europejczycy koncentrując się na pomaganiu większym firmom poprzez prokonkurencyjne badania oraz kładzenie większego nacisku na budowanie start-upów, 
w których budowaniu przodują USA. Japończycy zaś wprowadzili sztukę zarządzania krytycznymi technologiami w celu osiągania wzrostu produkcji przemysłowej, którą wpierają akademickie badania podstawowe i wdrożeniowe oraz system szkolenia oparty na symulacjach komputerowych. Stany Zjednoczone posiadają nadwyżkę mocy w zakresie podaży badawczej i niedokapitalizowane zasoby własności intelektualnej, które są ukierunkowywanie na potrzeby dużych, średnich i małych firm. Starają się pozyskać technologie od przedsiębiorstw i wprowadzać je do produkcji, zarówno w zakresie konwersji, jaki polityki rozwoju gospodarczego. Z drugiej strony Unia Europejska wydała w ostatnich latach ponad 100 mld euro na realizację Ramowych Programów, aby stać się bardziej konkurencyjną wobec USA, Chin i Japonii.

Programy partii politycznych zwykle ogniskują się wokół współpracy i integracji. Jednak należy oczekiwać, że projektowanie i wdrażanie coraz bardziej złożonych systemów opartych na wiedzy może generować i odtwarzać nierówności społeczne, wykluczenia i zróżnicowania. Pluralizm umożliwia bowiem, z jednej strony rozwój przejawiający się w coraz większej złożoności, a z drugiej, generuje konflikty organizacyjne, intergrupowe, interpersonalne oraz wymusza potrzebę dialogu i negocjacji. Analiza konfliktów i ich intensywności może być szczególnie użyteczna do:

- obserwacji i monitorowania wymiarów i parametrów dokonujących się procesów integracyjnych i dezintegracyjnych;

- oceny skuteczności metod i sposobów, jakie podmioty funkcjonujące w sieci wymiany procesy te są w stanie równoważyć, odtwarzać i optymalizować;

- identyfikacji, jakimi cechami nowo powstały system sieciowy różni się od już istniejących systemów?

- oceny czy powstał w nim nowy sposób generowania wiedzy i kontroli;

- oceny, jak zmiany w infrastrukturze wiedzy, umiejętności i kompetencji wpływają na intelektualną kondycję przedstawicieli poszczególnych nauk i dyscyplin naukowych, w tym ich funkcji i konsekwencji dla szkolnictwa wyższego?

Przedstawione powyżej problemy wskazują na ścisłe relacje zachodzące pomiędzy uniwersytetem, przemysłem i rządem, a szczególnie na potrzebę projektowania i wdrażania systemowego rozwoju 
technologii i instytucji oraz rolę badań naukowych prowadzonych w laboratoriach uniwersyteckich. Pomimo że wiele z nich skoncentrowanych jest na doświadczeniach USA i Wielkiej Brytanii, to dostępnych danych empirycznych o efektach tranzycji przejść od systemu krajowego do międzynarodowych ram tworzenia strategii $\mathrm{w}$ dziedzinie nauki i technologii oraz oficjalnych skutkach tych zmian jest wciąż niewiele informacji, wiedzy i wyników badań.

Jak twierdzi Judith Sutz można nawet mówić o niezapośredniczonej rzeczywistości między nauką a gospodarką, która, jej zdaniem, jest nową cechą potrójnej spirali. Rosnące zapotrzebowanie na fundusze ze strony uniwersytetów i instytutów badawczych generuje potrzebę wzajemnego wspierania się, co widoczne jest przede wszystkim w Niemczech, Holandii, Finlandii i W. Brytanii. Oznacza to potrzebę elastycznego łączenia się przedsiębiorstw i organów władzy publicznej, aby oferować uczelniom możliwość generowania nowej wiedzy i pobierania za nią opłat.

Władze polityczne miały i mają tendencje do interweniowania w procesy projektowania i zarządzania budową struktury wiedzy. Jednak obecnie są one bardziej refleksyjne w obszarze ograniczonej skuteczności swoich interwencji i negocjacji z pozostałymi dwoma podmiotami. Relacje między nimi są motywowane przez różne potrzeby takie jak finanse, wiedza czy legitymizacja władzy, a wynikające $\mathrm{z}$ nich wzorce w dużej mierze są trudne do pomiaru i przewidzenia ${ }^{23}$.

\section{Nowa rola uniwersytetu w sektorze produkcji i usług}

Odpowiedź na postawione pytanie wymaga zrozumienia złożoności przejścia z modelu trzech ról dydaktycznej, naukowej i badawczej do modelu z czterema rolami, w której czwarta zogniskowana jest na relacji ze społeczeństwem i gospodarką. Tak więc, uniwersytety polskie stanowią wczesny przykład tego rodzaju modelu. To, co jest czwartą nowością w trzeciej roli polega na eliminacji mediacji między wynikami a ich końcowymi użytkownikami. W dawnych czasach uniwersytet jako taki - z nielicznymi wyjątkami - nie pełnił funkcji charakterystycznej dla przedsiębiorstwa: nie sprzedawał swoich możliwości, nie

23 P.H. Dembiński, Finanse po zawale. Od euforii finansowej do gospodarczego ładu, tłum. Ł. Komuda, Wydawnictwo Studio Emka, Warszawa 2011, s. 18. 
zawierał umów określających produkt, który ma być dostarczony lub terminu dostawy $\mathrm{z}$ agentami uniwersyteckimi, aby efektywnie sprzedawać swoją inteligentną produkcję wiedzy, umiejętności i kompetencji.

W dawnych czasach przekazywanie wiedzy wytworzonej przez uniwersytet do jego użytkowników końcowych odbywało się poprzez pośredników, którzy pracowali w organach rządowych, centrach technologicznych oraz przedsiębiorstwach technologicznie powiązanych $\mathrm{z}$ wydziałami uniwersyteckimi. Obecnie w związku z przekształcaniem relacji uniwersytet - produkcja - rząd dochodzi do coraz głębszych zmian wewnątrz uniwersytetów. Wynika to z relacji zaangażowanego autora i kontekstu. Podejmując próbę rozstrzygnięcia tej kwestii należy zwrócić uwagę na mocne i słabe strony relacji władzy rządowej z uniwersytetami i sektorem produkcji porównując dorobek krajów wysoko rozwiniętych z jednej strony i słabo rozwiniętych z drugiej.

Podporządkowanie produkcji logicznej wiedzy, która podkreśla jej użyteczność, jest naturalne i zrozumiałe w sektorze produkcyjnym. Wiele jednak wskazuje, że zbyt duży nacisk położony na użyteczność musi być zrównoważony szybkimi efektami, użyteczna wiedza generowana przez uniwersytet jest dla firm istotnym krokiem $\mathrm{w}$ procesie poszerzania ich obszaru działania. W rzeczywistości niemożliwe jest wdrożenie szerokiej, specjalistycznej polityki rekrutacyjnej w firmie, bez względu na to, jakie strategiczne znaczenie ma wiedza w danym momencie. Nawiązanie bezpośredniej relacji z uniwersytetem zapewnia przedsiębiorstwu zestaw podstawowych danych wejściowych, które nie są dla nich tylko wydatkami. Ponadto, bezpośrednio stosowana wiedza jest coraz częściej wynikiem wymiany pomiędzy różnymi dyscyplinami, co czyni uniwersytet miejscem, w którym zwykle odbywają się interdyscyplinarne spotkania, będące jednocześnie najbardziej odpowiednią przestrzenią do jej produkcji. Rzeczywiście, nowy element nie tylko zwiększy bezpośrednie kontakty między światem akademickim a przedsiębiorstwami sfery produkcyjnej i usługowo-handlowej, ale także umowy będą przypominały dialog między równymi partnerami. Jeszcze nie tak dawno interesy, cele i style działania obu światów były zróżnicowane i uważano je za słuszne.

Obecnie zarówno uczelnie, jak i władza rządowa traktują się coraz bardziej jako niezależne podmioty, które są narodowym dobrem w budowaniu konkurencyjnej gospodarki, a nie tylko stanowią podmioty do 
budowania wiedzy dla samej wiedzy jako wartości autotelicznej. W zakresie, w jakim ta perspektywa jest społecznie akceptowana, granica pomiędzy środowiskiem akademickim a gospodarką ulega powolnemu zatarciu. Odzwierciedla się to w konkretnych metodach i zasadach współpracy między równymi partnerami. Przechodząc do kontekstu przedsiębiorcy zachowuje się on podobnie $\mathrm{w}$ relacjach $\mathrm{w}$ odniesieniu do potrójnej spirali relacji. Wyniki badań wskazują, że aktor biznesowy wnosi marginalny wkład w rozwój naukowy i technologiczny $\mathrm{w}$ państwach słabo rozwiniętych ${ }^{24}$. Ale to, co jest znane i interesujące to dominujące obecne i przyszłe trendy. Czy przedsiębiorcy w krajach rozwiniętych mogą próbować inicjować i rozwijać bliższe relacje z ośrodkami wytwarzania wiedzy? Czy skorzystają z mocy lobby, aby uruchomić potrójną spiralę? Tradycyjnie kraje te korzystały dla swojego rozwoju z zasobów wewnętrznych, opierając się przemianom i otwarciu swojej gospodarki. Im nie chodzi więc tylko o zacieśnianie powiązań z sektorem produkcji wiedzy, ale także o kontynuowanie koncentracji wysiłków na unikaniu konieczności uzupełniania importowanej podaży na rynek krajowy.

Badania nad analizą relacji zachodzących między uniwersytetami, przedsiębiorstwami i władzą wykonawczą w Polsce wymagają opracowania „Wielkiej Strategii Badań, Rozwoju i Innowacji”, aby dokonać rzetelnego opisu i wyjaśnienia: dlaczego dysponując posiadanymi zasobami ludzkimi, zasobami surowcowymi, badawczo-rozwojowymi pozostajemy ciągle na peryferiach tworzenia się branż nowoczesnych technologii oraz jakie działania należy podjąć, aby włączyć się w ten dominujący obecnie nurt badań i wykorzystania nowoczesnej techniki i technologii, tak jak zrobiła to kilkadziesiąt lat temu Japonia, a kilkanaście lat temu Australia, Korea Południowa i Finlandia? A ponadto, w jakich obszarach wiedza i badania empiryczne nad strukturami sieciowymi mogą nam pomóc $\mathrm{w}$ budowaniu nowych teoretycznych i empirycznych podstaw dla wdrażania potrójnej i poczwórnej spirali relacji i zależności?

Doświadczenia wspomnianych państw wskazują, że interakcje na poziomie sieci relacji generują:

24 A. Greenspan, Era zawirowań. Krok w nowy wiek, Wydawnictwo Literackie MUZA, Warszawa 2008, s. 282. 
- nowe potrzeby i oczekiwania wprowadzania zmian nie tylko o charakterze organizacyjno-instytucjonalnym, które mogą ułatwiać nawiązywanie strategicznych porozumień o współpracy;

- posiadanie nowoczesnych baz danych, w których zgromadzone są dane, informacje, a przede wszystkim wiedza o działalności gospodarczej staje się coraz bardziej istotną częścią architektury społeczeństwa wiedzy;

- konieczność stosowania proaktywnego, a nie klasycznego reaktywnego paradygmatu przez władzę rządową w formie polityki naukowej, technologicznej i innowacyjno-wdrożeniowej.

\begin{abstract}
The aim of the conceptual and constructivist efforts undertaken in the article was to present an outline of the evolution of network development and hyper-networks as well as a justification for the need to build increasingly complex social, economic, and public authorities. Such possibilities are created by the use of new concepts, methods, and ideas that not only precisely describe and explain complex relations of influence, but also indicate the need to strengthen the cooperation of an increasing number of institutions and organizations. It is a necessary process to design the next stages of learning and building multidimensional and multilevel interactions between universities, authorities, public administration, local and regional communities, and economic organizations. The author adopted Barton Clark's model as the first common theoretical platform for the presented issues. It consists of three elements: the academic oligarchy, the market, and state power. He then extended it to the model of a triple and quadruple spiral of socio-economic control relations according to the model of H. Etzkowitz and L. Leydesdorff, which reflect the relations between higher education institutions and the economy, society, and public authorities on the institutional, legal, cultural, and organizational level.
\end{abstract}

\title{
Bibliografia
}

Bitkowska A., Zarządzanie procesowe we współczesnych organizacjach, Wydawnictwo Difin, Warszawa 2013.

Bogason P., Zolner M., Methods in democratic network, McMillan, New York 2007.

Castells M., Himanen P., Społeczeństwo informacyjne i państwo dobrobytu, ze wstępem E. Benedyka, Wydawnictwo Krytyki Politycznej, Warszawa 2009.

Castells M., Koniec tysiąclecia, PWN, Warszawa 2008. 
Castells M., Społeczeństwo sieci, PWN, Warszawa 2008.

Chojnacki W., Człowiek w nowoczesnej organizacji. Wybrane problemy doradztwa personalnego i zawodowego, Wydawnictwo Adam Marszałek, Toruń 2006.

Chojnacki W., Kazimierowicz R., Kultura profesjonalna menedżerów firm strukturalnych, Wydawnictwo Akademii Humanistycznej w Pułtusku, Pułtusk 2019.

Chojnacki W., Wojsko i społeczeństwo w erze płynnej globalizacji, Wydawnictwo Wyższej Szkoły Wojsk Lądowych we Wrocławiu, Wrocław 2013.

Damodaran A., Ryzyko strategiczne, Wydawnictwa Akademickie i Profesjonalne, Warszawa 2009.

Dęmbinski P.H., Finanse po zawale. Od euforii finansowej do gospodarczego ładu, Wydawnictwo Studio Emka, Warszawa 2011.

Drucker P., Społeczeństwo pokapitalistyczne, PWN, Warszawa 1996.

Etzkowitz H., Leydesdorff L., Universities and the Global Knowledge Economy. A Triple Helix of University-Industry-Government Relations, edited by John de la Mothe and Gilles Paquet, London - Washington 1997.

Etzkowitz H., Losing our bearings: the science policy crisis in post-Cold War Eastern Europe, former Soviet Union and USA, „Science and Public Policy" 1996, t. 23, nr 1.

Gieryn T.E., Boundary-work and the demarcation of science form non-science: strains and interests in professional ideologies of scientists, „American Sociological Review” 1983, t. 48, nr 6.

Greenspan A., Era zawirowań. Krok w nowy wiek, Warszawskie Wydawnictwo MUZA, Warszawa 2008.

Karpiński A., Paradysz S., Soroka P. Żółtkowski W., Od uprzemysłowienia $w$ PRL do dezindustrializacji kraju, Warszawskie Wydawnictwo MUZA, Warszawa 2015.

Kieżun W., Drogi i bezdroża polskich przemian, Wydawnictwo EKOTV Sp. z o.o., Warszawa 2011.

Klein N., Doktryna szoku. Jak współczesny kapitalizm wykorzystuje klęski żywiołowe $i$ kryzysy społeczne, Warszawskie Wydawnictwo MUZA, Warszawa 2014.

Leśniewicz K., Mieli być nadzieją polskiej gospodarki, a biedują na uczelniach. Młodzi naukowcy nie mają łatwego życia. "Gazeta Prawna” 17.09.2018 r.

Levi-Stauss C., The Elementary Structures of Kinship, Boston Press, Boston 1969. 
Masłyk-Musiał E., Społeczeństwo i organizacje. Socjologia organizacji i zarządzania, Wydawnictwo Uniwersytetu Marii Curie-Skłodowskiej, Lublin 1999.

Modzelewski P., Opolski K., (red.) Metodologia pomiaru sieci administracji publicznej, Wydawnictwo CeDeWu. Warszawa 2014.

Nelson R., Economic Growth via the coevolution of Technology and Institution [w:] L. Leydesdorff, P. van de Besselaar (red.), Evolutionary Economic and Chaos Theory: New Directions in Technology Transfer, Palgrave MacMillan, London 1994.

Nelson R., Winter S., An Evolutionary Theory of Economic Change, Belknap Press of Harvard University Press, Cambridge MA 1982.

Noble D.F., Forces of Production, Knopf, New York 1984.

Parsons T., Plat G.M., The American University, Harvard University Press, Cambridge MA 1975.

Patologiczne aspekty polskiej prywatyzacji, Konwersatorium Polskiego Towarzystwa Ekonomicznego, 13.10.2016 r.

Pawłowska B., Doktór K. (red.), Dylematy współczesnych korporacji, Wydawnictwo Uniwersytetu Łódzkiego, Warszawa 2009.

Stachurski L., Kazimierz Twardowski wobec filozofii polskiej, [w:] W. Słomski (red.), Twórca szkoły lwowsko-warszawskiej w 70. Rocznicę śmierci Kazimierza Twardowskiego, Wydawnictwo Wyższej Szkoły Finansów i Zarządzania, Warszawa 2008.

Stiglitz J., Globalizacja, PWN, Warszawa 2004.

Sztompka P., Zaufanie. Fundament społeczeństwa, Wydawnictwo Znak, Kraków 2007.

Sztumski J., Systemowa analiza społeczeństwa, Wydawnictwo Śląsk, Katowice 2013.

Twardowski K., O dostojeństwie Uniwersytetu, „Zagadnienia Naukoznawstwa" 1990, nr 3.

Woleński J., Filozoficzna szkoła lwowsko-warszawska, PWN, Warszawa 1985.

Zacher L., Hybrydowy świat człowieka i ewolucja systemów socjotechnicznych, [w:] M. Sokołowski (red.), Sieciowe dyskursy (roz)poznawanie cyfrowego świata, Wydawnictwo Państwowej Wyższej Szkoły Zawodowej w Elblągu, Elbląg 2014. 